\title{
The Reasonableness in Recklessness
}

\author{
Findlay Stark ${ }^{1}[$
}

Published online: 3 July 2019

(c) The Author(s) 2019

\begin{abstract}
Recklessness involves unreasonable/unjustified risk-taking. The argument here is that recklessness in the criminal law is best understood as nevertheless containing an element of reasonableness. To be reckless, on this view, the defendant must reasonably believe that she is exposing others to a risk of harm. If the defendant's belief about the risk being imposed by her conduct is unreasonable, she should not (normally) be considered reckless. This point is most important in relation to offences of endangerment where recklessness sets the outer limits of criminal liability.
\end{abstract}

Keywords Mens Rea $\cdot$ Recklessness $\cdot$ Endangerment $\cdot$ Attempts

\section{Introduction}

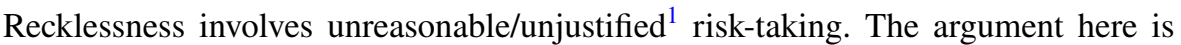
that recklessness in the criminal law is best understood as nevertheless containing an element of reasonableness. To be reckless, on this view, the defendant must reasonably believe that she is exposing others to a risk of harm. If the defendant's belief about the risk being imposed on others by her conduct is unreasonable, she should not (normally) $)^{2}$ be considered reckless. ${ }^{3}$

\footnotetext{
${ }^{1}$ I treat these terms as synonymous: see Findlay Stark, Culpable Carelessness: Recklessness and Negligence in the Criminal Law (Cambridge: Cambridge University Press, 2016), Ch. 1.

2 The "normally" caveat covers (presumably rare) cases where the defendant unreasonably over-estimates the probability of harm involved in $\Phi$ ing, but it would have been unjustified to run the (lower) risk that it would have been reasonable to believe existed in the circumstances. Such defendants, who should be considered reckless regarding the lower risk, will not be considered again until Sect. 7.

${ }^{3}$ In cases where there is an unreasonable under-estimation of risk, the defendant may instead be negligent: see Stark, Culpable Carelessness, Ch. 8.
}

Findlay Stark

fgs23@cam.ac.uk

1 Faculty of Law, University of Cambridge, Cambridge, UK 
The need for this reasonableness requirement becomes clearest through consideration of endangerment offences. Where recklessness marks the boundary of criminal liability for such offences, a belief-centred view of recklessness, which would not enquire into the reasonableness of the defendant's belief regarding the relevant risk, can conduce to over-criminalisation. Section 2 presents examples designed to trigger intuitive recognition of the potential harshness of this belief-centred approach. Sections 3 and 4 then suggest two responses to this problem. The first insists upon the presence of "concrete" endangerment, i.e., someone in fact being placed in harm's way by the defendant's conduct. ${ }^{4}$ This approach would over-privilege various forms of luck, and pay insufficient attention to culpability. The second response to the problem, requiring reasonable beliefs about risk, avoids these problems. ${ }^{5}$ Insights from the literature on the structurally similar problem of "factually impossible" attempts will be relied upon to advance this thesis. Remaining objections and clarifications to the reasonable-belief-based view of recklessness presented in Sect. 4 are considered in Sect. 5, before a definition of recklessness that reflects reasonableness' role within it is provided in Sect. 6. Section 7 then considers exceptional cases where the defendant's belief about risk is unreasonable, and yet a finding of recklessness remains justified.

\section{Problematising the Belief-Centred View of Recklessness}

The problem with a belief-centred view of recklessness is often veiled in real-life endangerment cases, because most defendants have what appear to be reasonable beliefs about the dangers involved in their conduct. Consider (an embellished version of) the English case of Parker. ${ }^{6}$ Parker was a lodger (an informal subtenant) in a semidetached Council house (a form of social housing) leased to Smith. ${ }^{7}$ Smith was dissatisfied with her accommodation. In a misguided attempt to help her, Parker set fire to Smith's sofa (couch) whilst she was out, hoping to render the house uninhabitable and cause the Council to rehome her. Parker did not check if his neighbours in the connected property were home before starting the fire. ${ }^{8}$ Assume, for the purposes of

\footnotetext{
4 The distinction between "concrete" and "abstract" endangerment is elaborated upon in Sect. 2.

5 The point could be made by reference to the comparable concept of justification for the relevant belief. There are, however, difficulties in probing defendants' precise justifications for forming particular beliefs. See Stark, Culpable Carelessness, pp. 135, 236-240.

6 " $R$ v Parker", Criminal Law Review, (1993): pp. 856-857 (E\&W). The issue in Parker arises not infrequently—see e.g., Cooper [2004] EWCA Crim 1382 (E\&W); Brewis [2004] EWCA Crim 1919 (E\&W); Harris [2013] EWCA Crim 223 (E\&W).

7 This is an invented name (no name is given in the case report).

8 If Parker believed that the connected home was unoccupied, he would not have been reckless, but only (potentially) negligent with regard to the risk of endangering another person's life (cf. Castle [2004] All E.R. (D.) 289 (Oct.) (E\&W)). Negligence is beyond the scope of this paper.
} 
this article, ${ }^{9}$ that Parker believed that his neighbours ${ }^{10}$ might be home and in danger of being killed in the fire.

Parker was charged with aggravated criminal damage, contrary to section 1(2) of the Criminal Damage Act 1971 (which applies to England and Wales):

(2) A person who without lawful excuse destroys or damages any property, whether belonging to himself or another

(a) intending to destroy or damage any property or being reckless as to whether any property would be destroyed or damaged; and

(b) intending by the destruction or damage to endanger the life of another or being reckless as to whether the life of another would be thereby endangered;

shall be guilty of an offence.

Parker's defence was that, as the neighbours had (it turned out) not been home at the time of the fire, their lives were never endangered.

Laypersons may think that Parker had a point. As a matter of ordinary English, it could be argued that "endangerment" requires that a particular interest was, colloquially, put "in harm's way". ${ }^{11}$ Limited support for this view can be found in dictionary definitions of "endanger": e.g., "to put someone or something at risk or in danger of being harmed, damaged, or destroyed"12. "put (someone or something) at risk or in danger". ${ }^{13}$ Unfortunately, for Parker, the criminal law detects an ambiguity in such ordinary-language definitions, and identifies two types of endangerment: "concrete" and "abstract".

\footnotetext{
${ }^{9}$ Parker's account was that he simply did not think of the neighbours. At the time, English law's approach to recklessness required merely that he took an unjustified risk that would have been obvious to the reasonable person: Caldwell [1982] A.C. 341 (E\&W). Nowadays, Parker would need to himself believe that the relevant risk existed at the time of starting the fire (or "close his mind" to that risk): $G$ and Another [2004] 1 A.C. 1034 (E\&W).

${ }^{10}$ Questions about whether Parker believed that fire fighters, etc. would necessarily respond to the blaze, and might be at risk of being killed, will be left aside. See, however, People v Rodriguez, 442 N.Y.S.2d 948 (1981) (NY); David Ormerod and Karl Laird, Smith, Hogan and Ormerod's Criminal Law, 15th edn. (Oxford: Oxford University Press, 2018), p. 1092.

${ }^{11}$ I am grateful to the anonymous reviewer for pushing this point.

$12 \mathrm{https} / / /$ dictionary.cambridge.org/dictionary/english/endanger.

${ }^{13} \mathrm{https} / / /$ en.oxforddictionaries.com/definition/endanger.
} 
As Antony Duff explains, ${ }^{14}$ borrowing from German criminal theory, ${ }^{15}$ "concrete" endangerment involves an interest actually being placed in harm's way by Фing ${ }^{16}$ : in Parker, the neighbours would have to be home at the time of the fire for their lives to have been "concretely" endangered. "Abstract" endangerment, by contrast, involves a situation where, although an interest was not put "concretely" in the path of harm by Фing, Фing is the type of activity that tends towards "concrete" endangerment, even if each token of that activity does not involve it. ${ }^{17}$ Starting a fire in a domestic property certainly can be that type of activity.

Parker's argument was "obviously a bad one", ${ }^{18}$ because aggravated criminal damage is clearly an offence of "abstract" endangerment: the defendant need only be "reckless as to whether the life of another would be thereby endangered", i.e., believe there is a risk of a "concrete" danger of death, and choose to continue without adequate justification. The question is whether, despite these points, Parker's argument should be sound in theory. Is there something in the use of recklessness without a requirement of "concrete" imposition of danger that renders such endangerment offences "sub-optimal" or "poorly drafted", as Alex Sarch has (tentatively) suggested ${ }^{19}$

The case for such sub-optimality is partly intuitive, and arises from consideration of more sympathetic examples than Parker. Sarch's own example involves section 211.3 of the Model Penal Code (MPC), which states that: "A person [commits an offense] if he threatens any crime of violence with purpose to terrorize another or to cause ... serious public inconvenience, or in reckless disregard of the risk of causing such terror or inconvenience". There is, again, no apparent requirement of "concrete" endangerment: the "external" elements are satisfied upon proof of the threat

\footnotetext{
14 Other authors draw this distinction differently. For instance, Andrew Simester and Andreas von Hirsch draw it along epistemic lines: if the defendant knows that he is not putting anybody at risk (e.g., he knows that the neighbours are out), that is an instance of "abstract" endangerment, whereas if the defendant does not know if he is putting anybody at risk, this is an instance of "concrete" endangermentCrimes, Harms and Wrongs: On the Principles of Criminalisation (Oxford: Hart, 2011), p. 76. This means that most cases of endangerment are "concrete", including all of the cases discussed here, thus draining the distinction of any useful content in this context. Andrew Ashworth and Lucia Zedner draw the distinction along the lines of the likelihood that someone will be in harm's way: if it $i s$ likely that someone will be in harm's way, that is an instance of "concrete" endangerment, whilst if it is not likely that someone will be in harm's way, that is an instance of "abstract" endangerment-Preventive Justice (Oxford: Oxford University Press, 2014), p. 102. If likelihood is assessed in terms of a reasonable belief that someone will be put in harm's way by the defendant's conduct, then this sense of "concrete" endangerment may accord with the view defended below. It is, however, unclear what Ashworth and Zedner would say about that precise point.

15 See, also, Markus Dubber and Tatiana Hörnle, Criminal Law: A Comparative Approach (Oxford: Oxford University Press, 2014), pp. 591-592.

16 R.A. Duff, Answering for Crime: Responsibility and Liability in the Criminal Law (Oxford: Hart, 2007), p. 163. See, also, Brenner Fissell, "Abstract Endangerment, Risk and the Politics of the Criminal Law”, American Criminal Law Review, 51(3) (2014): pp. 657-668, 667.

17 Another way of explaining this idea is in terms of the combatting of "potential risks", if "risks" is understood in a "concrete" manner here: Fissell, "Abstract Endangerment", p. 657.

18 See J.C. Smith's commentary on Parker in " $R v$ Parker", p. 857.

19 Alexander Sarch, "Review of Findlay Stark, Culpable Carelessness", Criminal Law and Philosophy, 12(4) (2018): pp. 725-730, 728-729.
} 
of a crime of violence. The remaining heavy lifting, in terms of criminal liability for endangerment, is done by the defendant's mental state of purpose or recklessness with regard to "concrete" danger.

Sarch's example is as follows ${ }^{20}$ :

Suppose Falecia has a terrible sense of humor and thinks it would be hilarious to call Warner Brothers Studios and threaten to "drug everyone there to death." She does not intend to terrorize or inconvenience people, but genuinely believes there is a substantial risk that this will result from her prank. However, suppose her belief is simply false. Falecia's voice sounds exactly like the adorable cartoon character Tweety Bird $\left[{ }^{21}\right]$ from the Warner Brothers TV show Looney Tunes. Thus, no one hearing her would understand her to be menacing in the slightest. Indeed, any listener on the phone would misunderstand her as saying that she wants to hug everyone there to death. Accordingly, there actually exists no risk that terror or serious public inconvenience will result from Falecia's prank.

Sarch worries that it may be "overly harsh" to convict Falecia, ${ }^{22}$ and that a beliefcentred view of recklessness (specifically, mine) ${ }^{23}$ may thus lead to "implausible" results. ${ }^{24}$ Despite her culpable choice, made in the light of her beliefs about the "concrete" dangers her conduct would impose on others, the legislature might, on grounds of "e.g., ... compassion, generosity or political prudence" decide not to define offences of endangerment so as to capture actors like Falecia. ${ }^{25}$

A difficulty with Sarch's example is that it is hard to make sense of Falecia's "prank" if she lacks the purpose of being taken seriously, thus causing at least "serious public inconvenience". ${ }^{26}$ Presumably, if she is not believed, the "prank" fails. ${ }^{27}$ Sarch's example can be fleshed out to avoid this problem. Perhaps Falecia's friend works at the studio, and she intends that he answers and is personally afraid (momentarily), before Falecia reveals it is a "prank". She believes, however, that there is a risk that her friend might over-react, causing "serious public inconvenience". Given Sarch's stipulations, there is at least a case to be made for the unreasonableness of such a belief, but Falecia nevertheless formed it. If the belief-centred view of recklessness is correct, then Falecia is guilty of the MPC offence.

Sarch's example may trigger the right sort of intuition about the harshness of a belief-centred view of recklessness in this context, but it is slightly eccentric. Paul

\footnotetext{
20 Sarch, "Review", p. 729.

21 A.k.a. Tweety Pie, particularly in the UK. (I never thought I would write this footnote, either.).

22 Sarch, "Review", p. 729.

23 See Stark, Culpable Carelessness, Chs. 4-6.

24 Sarch, "Review", p. 728. Another way of expressing the same idea is that a belief-based view of recklessness is "extreme, but not (quite) absurd"-see Kenneth Simons, "Retributivism Refined-or Run Amok?", The University of Chicago Law Review, 77(1) (2010): pp. 551-584, 554.

25 Sarch, "Review", p. 730.

26 I am grateful to Christopher Cowley for nudging me to clarify this point.

27 See R.A. Duff, Intention, Agency and Criminal Liability: Philosophy of Action and the Criminal Law (Oxford: Basil Blackwell, 1990), p. 61.
} 
Robinson provides a more realistic example, based on the offence of reckless endangerment contained in section 211.2 of the MPC: "A person commits a misdemeanor if he recklessly engages in conduct which places or may place another person in danger of death or serious bodily injury". The wording is, once again, clear on this offence's non-"concrete" nature ("places or may place ..."). ${ }^{28}$ Recklessness regarding the relevant "concrete" dangers can once again do the heavy lifting in terms of liability.

Robinson's example is as follows ${ }^{29}$ :

Consider a single-parent law professor [call him Kasper] scheduled to bring his children to a conference in Israel. Television reports from the area show what is essentially a war zone. He is anxious to attend the conference, however, so he disregards the serious risk to his children and goes to the conference as planned. Once he arrives, he realizes that all of the violence is in Ramallah[ $\left.{ }^{30}\right]$ and that there is no danger of violence in Tel Aviv, the site of the conference. Having never been to Israel, he had incorrectly assumed that the Ramallah violence threatened Tel Aviv. His children are not and never have been in danger.

Robinson assumes that "most people" would not want Kasper to be convicted of reckless endangerment, because he "did not put his children in danger; he only mistakenly believed that he had". ${ }^{31}$ If the belief-centred view of recklessness is correct, however, Kasper is guilty.

Intuitions will no doubt vary in outcome and in strength in relation to these examples. They nevertheless raise a worry about the belief-centred view of recklessness' plausibility when recklessness regarding "concrete" endangerment sets the boundaries of liability for endangerment offences. ${ }^{32}$ One might be tempted, on the basis of

\footnotetext{
28 See Michael Cahill, "Attempt, Reckless Homicide and the Design of Criminal Law", University of Colorado Law Review, 78(3) (2007): pp. 879-956, 925-926; Duff, Answering for Crime, p. 163. Cf. Peter Westen, “The Ontological Problem of 'Risk' and 'Endangerment' in Criminal Law”, in R.A. Duff and Stuart Green (eds.), Philosophical Foundations of Criminal Law (Oxford: Oxford University Press, 2010), p. 309; American Law Institute, Model Penal Code and Commentaries: Part 1-General Provisions (Philadelphia, PA: American Law Institute, 1980), pp. 197, 203.

29 Paul Robinson, "Prohibited Risk Creation and Culpable Disregard or Inattentiveness: Challenge and Confusion in the Formulation of Risk-creation Offenses", Theoretical Inquiries in Law, 4(1) (2003): pp. 367-396, 385.

${ }^{30}$ Robinson does not explain the significance of these locations, and it is not self-evident. Ramallah is approximately $39 \mathrm{~m} / 63 \mathrm{~km}$ from Tel Aviv, and there is a national border and other cities between the two locations. Presumably, then, the inference to be drawn is that the distance and barriers in place mean that Tel Aviv is not credibly threatened by the violent unrest. The need for such an explanation/inference suggests that the example is not as simple as Robinson suspects, which is the conclusion that will be arrived at below in Sect. 4.

31 Robinson, "Prohibited Risk Creation", p. 385. Indeed, Robinson fears that the MPC would convict Kasper of manslaughter if the children were unexpectedly killed by terrorists: p. 385.

32 Robinson's own solution is to split off the idea of "prohibited risk" (a "rule of conduct") from recklessness (a "rule of adjudication"). The "risks" at issue ultimately appear to be determined by reference to the reasonable person's standpoint (e.g., Robinson, "Prohibited Risk Creation", p. 386). This makes Robinson's solution potentially similar to the one provided below, but the point is not entirely clear. Furthermore, a large part of the case for splitting "prohibited risks" from recklessness concerns situations where risk is mentioned, but a fault element regarding those risks is not required. My sympathies lie with the view that such offences of strict liability endangerment are illegitimate (see n. 38, below).
} 
these examples, to hold that it must be "true" that the relevant danger in fact existed before liability for an offence premised on reckless endangerment can follow. The next sections explore two possible understandings of this requirement.

\section{Requiring "Concrete" Endangerment}

The first response to the problem identified in Sect. 2 would be to insist that those offences should be interpreted to require "concrete" endangerment of the relevant interests. On such views, "the mere apparent ability to inflict harm [would] not [be] sufficient" for liability. ${ }^{33}$ This would lead to the acquittal of all of the defendants discussed thus far.

It is possible, but rare, to find endangerment offences that at least appear to insist on "concrete" endangerment in this manner. For example, section 5.1.28 of the Australian Model Criminal Code states that: "A person: (a) whose conduct gives rise to a danger of death to any person, and (b) who is reckless as to the danger of death to any person that arises from that conduct, is guilty of an offence." Without more, subsection (a) might be read to require that a "concrete" danger is in fact caused to a person's life as an "external" element ("gives rise to a danger ..."), independent of the fault element of recklessness contained in subsection (b) ${ }^{34}$ There is, however, an important caveat in section 5.1.27(4): “... it is not necessary to prove that a person was actually placed in danger of death or serious harm by the conduct concerned". With that, the "concrete" cracks.

It is easy to see why "concreteness" is eschewed in the model Australian offence, and in the offences mentioned in Sect. 2. The only real argument in favour of requiring "concrete" endangerment is as follows: if it is legitimate to criminalise $\Phi$ ing, because $\Phi$ ing involves harm $x$, then it is unproblematically legitimate to criminalise Фing if it carries with it the "concrete" danger of harm $x$ materialising. ${ }^{35}$ Any plausible conception of the harm principle will accommodate such "primary" risks of harm $x .{ }^{36}$ "Abstract" endangerment, by contrast, involves the criminalisation of risks of "concrete" danger, which at first might be thought to rule out more conduct, and thus be more problematic in criminalisation terms.

This is, however, a weak argument for requiring proof of "concrete" endangerment. First, citizens often will not know, ex ante, if interests are "concretely" being put in danger by $\Phi$ ing. ${ }^{37}$ Requiring "concrete" endangerment does not, then, actually

\footnotetext{
33 Commonwealth v Trowbridge, 261 Pa. Super. 109, 115 (1978) (PA). See, further, Westen, "The Ontological Problem of 'Risk'”, p. 309.

34 A similar approach could be adopted within the definition of recklessness, itself-e.g., in Wisconsin, where recklessness exists where "the actor creates an unreasonable and substantial risk ... [and] is aware of that risk": Wisconsin Criminal Code, s. 939.24(1) (WI).

35 Duff, Answering for Crime, p. 161; Douglas Husak, Overcriminalization (Oxford: Oxford University Press, 2007), p. 39.

36 Simester and von Hirsch, Crimes, Harms and Wrongs, p. 76.

37 Simester and von Hirsch, Crimes, Harms and Wrongs, p. 77.
} 
help citizens to plan their conduct so as to avoid liability, meaningfully preserving a wider sphere of personal freedom.

Second, consider cases, like those in Sect. 2, where recklessness regarding the relevant endangerment is necessitated. ${ }^{38}$ A risk of a "concrete" danger of harm $x$ is, in reality, just a (lower) risk of ultimate harm $x .{ }^{39}$ Consider if there was a $50 \%$ chance that Parker's neighbours would have been killed if they had been home, and a $10 \%$ chance they were home. This suggests that there was a 5\% chance of their being killed. Two points flow from this. First, if "substantial" risk-taking is required for recklessness (which is plausible, if controversial), ${ }^{40}$ then at some point the risk that ultimate harm $x$ will occur will not require justification, given its small size. Secondly, if the risk of ultimate harm $x$ is substantial enough to warrant justification, it will be easier to justify the risking of ultimate harm $x$ at a certain level of removal. Justifying "concretely" risking somebody's life, for example, is harder to justify than risking that the conditions might arise where somebody's life will "concretely" be put at risk. It is even easier to justify taking the risk that conditions might arise where somebody's life might be "concretely" endangered, and so on. At some stage, the ease of justification will remove any meaningful impact on citizens' freedom. ${ }^{41}$

There are further convincing reasons to reject a requirement of "concrete" endangerment. ${ }^{42}$ First, "concrete" endangerment imposes law-enforcement costs in establishing whether a person was in fact in harm's way, which will not always be clear. ${ }^{43}$

Second, it is not clear that such costs would be worth bearing in principle: a requirement of "concrete" endangerment pays insufficient regard to equivalence in moral culpability. ${ }^{44}$ Consider, an identically placed defendant to Parker, Barker, who sets a fire in identical circumstances, with the same beliefs about the circumstances and the risk of death arising from them. Barker's neighbours are, however, home

\footnotetext{
38 It is not essential for offences of "abstract" endangerment to require a mens rea state (whether recklessness or negligence) regarding the relevant risk(s) or harm(s). The defensibility of offences of endangerment that do not require a fault element regarding the relevant dangers is beyond the scope of this paper, but see Ashworth and Zedner, Preventive Justice, p. 115. My sympathies lie with the view that such offences (and, indeed, other offences of "strict liability") are indefensible, but advancing that view fully is impossible in the space available here.

39 Victor Tadros, Criminal Responsibility (Oxford: Oxford University Press, 2005), p. 255. See, too, David Lanham, “Danger Down Under”, Criminal Law Review, (1999): pp. 960-969, 963.

40 My view is that the legislature should have to show that a particular, problematic level of risk-taking existed before it can require citizens to answer publicly for their conduct. The level of "substantial" risktaking need not be static across risked interests. See Stark, Culpable Carelessness, pp. 11-16. Cf. Larry Alexander and Kimberly Kessler Ferzan with Stephen Morse, Crime and Culpability: A Theory of Criminal Law (Cambridge: Cambridge University Press, 2009), pp. 25-27.

41 This demonstrates how mens rea terms can set more acceptable limits on criminalisation decisions. See Winnie Chan and A.P. Simester, "Four Functions of Mens Rea", Cambridge Law Journal, 70(2) (2011): pp. 381-396, 393-395.

${ }^{42}$ It has also been argued that utilising "abstract" endangerment reduces the risk of over-zealous interrogation of the safety of activities by the state: Simester and von Hirsch, Crimes, Harms and Wrongs, p. 77. As will be noted in Sect. 5, however, "abstract" endangerment may, if combined with a belief-centred view of recklessness, be very intrusive.

43 Simester and von Hirsch, Crimes, Harms and Wrongs, p. 77.

44 Hereinafter, I will use "culpability" to stand in for "moral culpability". Where (so to speak) "legal culpability" differs, this will be indicated explicitly.
} 
when she starts the fire. Both Parker and Barker believe that $\Phi$ ing will expose others to a substantial risk of the relevant harm, and choose to $\Phi$ without adequate justification. These choices demonstrate the same level of insufficient concern for the interests of others, ${ }^{45}$ generally taken to be the gist of culpability. ${ }^{46}$ For authors such as Larry Alexander and Kim Ferzan, then, unless these defendants satisfy the conditions of a mental condition defence, ${ }^{47}$ both may ${ }^{48}$ be punished to the extent that their culpable choices warrant. ${ }^{49}$ Yet if aggravated criminal damage were to require "concrete" endangerment (as Parker contended), Parker would be acquitted and Barker convicted. Such an outcome would over-privilege (various forms of) $\operatorname{luck}^{50}$ and downplay Parker's equal culpability.

The case against "concrete" endangerment is convincing. There remains an important question, though: how does one decide on the boundaries of any alternative? Requiring "abstract" endangerment does not, in itself, answer this question, at least without an understanding of what it means to take a risk of "concrete" endangerment. Should we, adopting Alexander and Ferzan's view, allow any conduct that the defendant believes exposes others to a risk of the relevant "concrete" danger ${ }^{51}$ (provided that risk-taking is unjustified) to be the basis of endangermentbased liability? This would mean convicting all of the defendants in Sect. 2, which has already been recognised as intuitively questionable. The next section contends that there is a principled middle road between this intuitively harsh, beliefcentred approach and "concrete" endangerment's blunt insensitivity to concerns of culpability.

\section{Requiring Reasonable Beliefs About Risk}

The germ of the solution to the dilemma in Sect. 2 is identified by Sarch, who suggests that "awareness of risk"- a core component of many accounts of recklessness in Anglo-American criminal law ${ }^{52}$ - could be construed in terms of a "true belief

\footnotetext{
45 See, e.g., Alexander and Ferzan with Morse, Crime and Culpability, pp. $86-87$ (n. 2), 94, 152, $195-$ 196, 222-223. See, also, Larry Alexander and Kimberly Kessler Ferzan, "Danger: The Ethics of Preemptive Action", Ohio State Journal of Criminal Law, 9(2) (2012): pp. 637-668.

${ }^{46}$ See Stark, Culpable Carelessness, p. 3 and the sources cited there.

47 Alexander and Ferzan with Morse, Crime and Culpability, pp. 45-46, 223 (n. 23).

${ }^{48}$ For them, culpability is the basis of desert, but deserved punishment need not be pursued if this would be unduly costly: Alexander and Ferzan with Morse, Crime and Culpability, pp. 7-9.

${ }^{49}$ Alexander and Ferzan with Morse, Crime and Culpability, p. 193. See, too, Robinson, "Prohibited Risk Creation", p. 387.

${ }^{50}$ In Nagelian terms, a mixture of at least two types of luck: "circumstance" luck ("the kind of problems and situations one faces") and "outcome" luck ("luck in how one's actions and projects turn out"): see Thomas Nagel, Mortal Questions (Cambridge: Cambridge University Press, 1979) p. 28.

${ }^{51}$ A defendant who believes that there are risks attendant upon Фing is secure from liability for an offence premised on reckless endangerment unless and until she believes that she is $\Phi$ ing. Sitting at one's desk, abstractly contemplating the risks to life associated with the (mis)use of certain gas appliances, does not turn one into a reckless endangerer of life. See Stark, Culpable Carelessness, p. 120.

${ }^{52}$ See Stark, Culpable Carelessness, Ch. 2.
} 
that the risk exists". ${ }^{53}$ Sarch points out that "awareness" is a "factive" mental state ${ }^{54}$; "necessarily, one has it only to truths". ${ }^{55}$ Belief, by contrast, is non-factive-which gives rise to the dilemma at the core of this paper.

It is unclear from Sarch's brief explanation what he thinks a "true" belief in risk consists in. ${ }^{56}$ It has already been demonstrated that it should not be understood in terms of requiring "concrete" endangerment. Are there workable alternatives that do not simply collapse into a belief-centred view of recklessness?

Alexander and Ferzan suggest that the answer is "no", arguing in favour of assessing "the risk" that existed in any given circumstance exclusively in terms of the defendant's own ("subjective") beliefs. ${ }^{57}$ In other words, for the defendant to "truly" be risking the interests of others by $\Phi$ ing would simply be for her to believe that such a risk attends Фing (and that she is Фing).

Their argument proceeds from the well-known point that risks only make sense in the light of incomplete factual information. ${ }^{58}$ With complete information, either the outcome will happen (probability $=1$ ) or it will not (probability $=0$ ). If that is the "truth" of the matter, no reckless defendant (i.e., a person who believes the harmful outcome's probability is somewhere between 0 and 1) will have a "true" belief about risk. Risk is an incoherent notion from this perspective.

If it is to do any work conceptually, risk must accordingly be based on an assessment carried out with incomplete information from the $e x$-ante perspective. ${ }^{59}$ Alexander and Ferzan contend, however, that there is no non-arbitrary way to establish which pieces of information will be taken into account in establishing what risk of harm exists, apart from simply taking the defendant's beliefs (however misguided) to be determinative. ${ }^{60}$ If this is what it is for a risk to "truly" exist, ${ }^{61}$ then every defendant will see the "true" answer, ex ante. A belief-centred view of recklessness follows inexorably from this conclusion.

\footnotetext{
53 Sarch, "Review", p. 730. In a footnote (n. 5), Sarch deals with differences between true beliefs and knowledge (which is, like awareness, factive). This makes it unnecessary to rehearse objections to understanding awareness of risk (and thus recklessness and negligence) in terms of knowledge about risks. Compare Stark, Culpable Carelessness, Ch. 5 and Douglas Husak, "Negligence, Belief, Blame and Criminal Liability: The Special Case of Forgetting", Criminal Law and Philosophy, 6(3) (2011): pp. 199-218.

54 See, too, Jennifer Nagel, "Factive and Nonfactive Mental State Attribution", Mind and Language, 32(5) (2017): pp. 525-544, 530.

55 Timothy Williamson, Knowledge and Its Limits (Oxford: Oxford University Press, 2002) p. 34.

56 This is not his fault; the suggestion is included in a book review.

57 Alexander and Ferzan with Morse, Crime and Culpability, pp. 27-31.

58 For an overview, see Stark, Culpable Carelessness, pp. 16-20. For analysis of this point in relation to the MPC, see David Treiman, "Recklessness and the Model Penal Code", American Journal of Criminal Law, 9(3) (1981): pp. 281-386, 318-322. I set aside issues of quantum indeterminacy.

59 See, too, Robinson, "Prohibited Risk Creation", p. 386.

60 Alexander and Ferzan with Morse, Crime and Culpability, pp. 29-30.

61 I assume here that Alexander and Ferzan mean to take (1) the defendant's beliefs about "the risk" (e.g., the chances of harm $x$ materialising) as determinative, rather than (2) the defendant's beliefs about the facts, from which "the risk" is calculated in a more "objective" way (compatibly with what is said below). This is not always clear.
} 
Alexander and Ferzan are not right, however, that all alternative conceptions of "true" risk are wildly unfair, such that their use in the criminal law would be completely objectionable. First, following Eric Johnson, ${ }^{62}$ one could contend that the "true" risk that the defendant was taking should be assessed in the context of the circumstances as the defendant believed them to be, unless any of those beliefs were provably false. ${ }^{63}$ If the defendant has a provably false belief about a circumstance, that circumstance and belief are simply ignored in calculating the relevant risk for the purposes of criminal liability. Say Parker starts his fire on a Wednesday at $3 \mathrm{pm}$. He believes that his neighbours are retired, and so tend to be home at that time of day through the week. In fact, his neighbours are in full-time employment and tend to be home at that time of day only during the weekend. On Johnson's approach, Parker's false belief about his neighbours' employment status (and that particular circumstance) would be removed from the analysis of the "true" risk he was taking of "concretely" endangering their lives. One could then contend that Parker was not reckless regarding endangering his neighbours' lives, because his belief about that risk of "concrete" danger did not match the "true" danger to the neighbour's lives his act of arson in fact produced.

Johnson's argument works well where the "truth" of beliefs about circumstances is readily apparent-whether Parker's neighbours were home is, for example, presumably simple enough to work out-but other circumstances will be far less clear. Although not unruly and arbitrary, Johnson's view may be impractical. This shortcoming is overcome by John Oberdiek, who would ask the following question to assess what the "true" risk was: what is the gravest probability of harm that the reasonable person would have estimated, ex ante, given the evidence available to the defendant? ${ }^{64}$ If the defendant made an unreasonable mistake about the level of risk involved in $\Phi$ ing, his belief would not be determinative of the "true" risk sought to be justified. Oberdiek's view endorses a third way of looking at probability (and risk), which theorists such as Alexander and Ferzan tend to under-privilege: the view that probabilities are determined not only by the facts (chances), or by an agent's "subjective" beliefs (credences), but also by reference to the evidence available, ex ante, of a certain proposition. ${ }^{65}$

It is worth noting that this reasonableness-based solution finds support in the literature on (one form of) "factually impossible" attempts. The relevant difficulty in such "factually impossible" attempts and the types of endangerment case presented

\footnotetext{
62 Eric Johnson, "Is the Idea of Objective Probability Incoherent?", Law and Philosophy, 29(4) (2010): pp. 419-432; Eric Johnson, "Knowledge, Risk and Wrongdoing: The Model Penal Code's Forgotten Answer to the Riddle of Objective Probability", Buffalo Law Review, 59(2) (2011): pp. 507-584.

63 I endorsed Eric Johnson's solution in Stark, Culpable Carelessness, pp. 19-20. I am now more minded to accept John Oberdiek's view, discussed below.

64 John Oberdiek, Imposing Risk: A Philosophical Analysis (Oxford: Oxford University Press, 2017), Chs. 1-2.

65 See David Mellor, Probability: A Philosophical Introduction (London: Routledge, 2005), Ch. 1. See, also: Victor Tadros, The Ends of Harm: The Moral Foundations of Criminal Law (Oxford: Oxford University Press, 2011), Ch. 10; Oberdiek, Imposing Risk, Ch. 2. I am grateful to Alexander Greenberg for encouraging me to clarify this point.
} 
by Sarch and Robinson is the same: taking the defendant's beliefs to be determinative of criminal liability can lead to counter-intuitive, harsh results. ${ }^{66}$ The option again exists to hold all such actors (absent a mental condition defence) liable for their attempts. This is indeed Alexander and Ferzan's position, ${ }^{67}$ and is sometimes found doctrinally. ${ }^{68}$

Factual impossibility is, nevertheless, a "perennially thorny problem" 69 in theory and doctrine precisely because this approach appears too quick in certain (unusual) cases. This intuitive rashness accounts for an element of theoretical hesitation in the case of obviously doomed attempts. ${ }^{70}$ A similar reluctance is indicated by doctrinal responses to clearly impossible attempts, such as the encouragement of the exercise of prosecutorial discretion in favour of not proceeding, ${ }^{71}$ rules allowing for the dismissal of proceedings, ${ }^{72}$ or substantive criminal law rules excluding liability. ${ }^{73}$

This trepidation can be explained on the basis of the lack of "dangerousness" of such attempts (if not also those who perform them-a point to be returned to below). It might, for instance, be that the only attempts that should be criminalised are those that pose a "real" social danger. ${ }^{74}$ The difficulty has been working out a coherent way to establish whether such a "real" danger existed, which mirrors the debate about what a "true" risk of "concrete" danger is in relation to the endangerment offences introduced above.

Without rehearsing the whole debate, the relevant answer for present purposes focuses on whether the defendant's conduct would have made a reasonable observer (or some related heuristic device) ${ }^{75}$ fear that the threatened harm may occur. ${ }^{76}$ This approach requires attempts to have a manifested connection with the world of reasonableness, which has been variously expressed in terms of "aptness" for success, ${ }^{77}$

66 George Fletcher, Rethinking Criminal Law (Boston, MA: Little \& Brown, 1978), p. 160.

67 Alexander and Ferzan with Morse, Crime and Culpability, pp. 194, 221-223.

68 E.g., MPC s. 5.01(1); Criminal Attempts Act 1981, ss. 1(2)-1(3) (E\&W).

69 Stephen Morse, "Reasons, Results, and Criminal Responsibility", University of Illinois Law Review (2004): pp. 363-444, 391.

70 R.A. Duff, Criminal Attempts (Oxford: Oxford University Press, 1996), p. 115; Fletcher, Rethinking Criminal Law, pp. 176-177.

71 See, e.g., A.P. Simester, J.R. Spencer, Findlay Stark, G.R. Sullivan, and G.J. Virgo, Simester and Sullivan's Criminal Law: Theory and Doctrine, 6th edn. (Oxford: Hart, 2016), p. 364; Ormerod and Laird, Smith, Hogan and Ormerod's Criminal Law, p. 498.

72 E.g., MPC, s. 5.05(2).

73 E.g., M.S.A. s. 609.17 (MN).

74 See Thomas Weigend, "Why Lady Eldon Should be Acquitted: The Social Harm of Attempting the Impossible", DePaul Law Review, 27(2) (1977): pp. 231-274. Cf. Gideon Yaffe, Attempts: In the Philosophy of Action and the Criminal Law (Oxford: Oxford University Press, 2010), pp. 242-243.

75 Usually, the reasonable person (or some such standard) is utilised. Cf. the reasonable expert standard proposed in Lawrence Crocker, "Justice in Criminal Liability: Decriminalizing Harmless Attempts", Ohio State Journal of Criminal Law, 53(4) (1992): pp. 1057-1110, critiqued well in Peter Westen, "Impossibility Attempts: A Speculative Thesis", Ohio State Journal of Criminal Law, 5(2) (2008): pp. 523-566, 545 .

76 This is something of a mixture of views. The differences between them are hopefully not important here.

77 Fletcher, Rethinking Criminal Law, p. 150. 
there being a "real prospect of success", 78 and of "citizens of the jurisdiction ... regard[ing] the actor's conduct as a threat to interests that the statute seeks to protect". ${ }^{79}$ Consider Duff's test regarding factually impossible attempts ${ }^{80}$ :

A defendant should be acquitted only if the intention with which he acted radically failed to engage with the world or if his action (as appropriately described) was obviously and completely unsuitable as a way of trying to [actualize] his criminal intention: if anyone exercising ordinary intelligence, and a basic knowledge of the world, would realize that it could not hope to succeed. Such conditions will not often be satisfied except by those who are mentally disordered or defective.

This test can be adapted for cases of reckless endangerment. It would require that a defendant should not be found to have recklessly endangered a particular interest if her belief that the relevant "concrete" danger might follow was one that nobody exercising ordinary intelligence, and possessing a basic knowledge of the world, would have formed. ${ }^{81}$ Another way of explaining the same idea is in terms of a requirement that the defendant not only believed that $\Phi$ ing carried with it the risk of a "concrete" danger of harm, but that this belief was a reasonable one to hold. Like Duff's test for attempts, this would commonly be a "stealth" requirement: most sane defendants will satisfy it easily. ${ }^{82}$

Tests of this sort can identify cases where it becomes inapposite to describe the success or failure of an attempt in terms of "luck" ${ }^{83}$ Similarly, when one unreasonably believed that Фing might result in "concrete" endangerment, it is not really a matter of "luck" that the relevant "concrete" danger did not materialise. ${ }^{84}$ It is credible to conceive of Parker as "lucky", because it was readily plausible that his action would "concretely" imperil the lives of his neighbours, as Barker's did. Parker and Barker could not control whether the neighbours were home, and they plausibly (depending on their schedules, etc.) could have been. Any reasonable person in those defendants' ex-ante position, with their identical set of background beliefs about the circumstances and the dangers involved in their conduct, and the evidence available to them, would credibly have drawn the same conclusion: starting a fire will impose a certain level of risk of "concrete" danger to the neighbours' lives (a level of risk that it is unjustified to take).

\footnotetext{
78 R.J. Spjut, "When Is An Attempt To Commit An Impossible Crime A Criminal Act?", Arizona Law Review, 29(2) (1987): pp. 247-280, 278.

79 Westen, "Impossibility Attempts", p. 560.

${ }^{80}$ Duff, Criminal Attempts, p. 232. Cf. Yaffe, Attempts, pp. 251-254.

81 Compare New York Penal Law 150.15 (NY) (defining "arson in the second degree"), which-instead of reasonable perception of risk-requires an "apparent possibility" of harm. This test leaves unresolved the crucial question: apparent to whom?

82 For the idea of "stealth" requirements, see Westen, "Impossibility Attempts", p. 548.

83 See Duff, Criminal Attempts, pp. 226, 231-232, 333, 380. See, also, Bebhinn Donnelly-Lazarov, A Philosophy of Criminal Attempts (Cambridge: Cambridge University Press, 2015), pp. 145-147.

${ }^{84}$ It is, of course, "lucky" that the defendant was so constituted as to form the unreasonable belief, but resolving the issue of "constitutive" luck (and its implications for the free will/determinism debate) is beyond the scope of this paper.
} 
Contrast, Falecia's case. Sarch's stipulations perhaps make it unreasonable for Falecia to believe that there is a risk of a "concrete" danger serious public inconvenience. It is, accordingly, less plausible to say that Falecia is "lucky" that her conduct does not result in a "concrete" danger of serious public inconvenience materialising.

Kasper's case is more difficult. It turns, in part, on the matter of how well-known the geography of Israel is, and how this information bears upon the question of whether violence might spread, and thus whether Kasper formed a reasonable belief that there was a possibility that he was putting his children in "concrete" danger. If that was a reasonable belief to have formed, there is good reason to punish Kasper for reckless endangerment, despite his children's lives never having been 'concretely" endangered. In such circumstances, it is plausible to say that Kasper was "lucky" that that "concrete" danger did not materialise, and it would under-play his culpability to acquit him.

Peter Westen provides an alternative response, which might be thought to be more precise than the one about reasonable beliefs defended here. ${ }^{85}$ His approach asks the finder of fact to consider whether it fears that the defendant's conduct came "close enough" to causing harm, insofar as the relevant counter-factual circumstances in which the ultimate harm would have materialised are thought to be readily possible. ${ }^{86}$ This is a matter of "how easily fact-finders can imagine the occurrence of counterfactual conditions under which the fateful harms would have occurred". ${ }^{87}$ It is not clear, however, how different this test is from one premised on the reasonableness of the defendant's belief that he is exposing others to a risk of "concrete" danger. Presumably ordinary citizens would view the harm as sufficiently "close" when it was reasonable (from an ordinarily knowledgeable bystander's perspective) for the defendant to believe that someone could be "concretely" endangered by his conduct.

It has been argued that a reasonable-belief-based view of recklessness can avoid the pitfalls of a requirement of "concrete" endangerment with regard to equal culpability and "luck", whilst avoiding the intuitive harshness of a beliefbased view of recklessness that does not enquire into reasonableness. Adding in a condition of reasonableness in recklessness will, however, require more information to be available than a simpler, belief-centred view. Indeed, the main objection to the reasonable belief-based view of recklessness defended here is that it would unnecessarily complicate matters. The next section addresses such concerns.

\footnotetext{
${ }^{85}$ See Westen, "Impossibility Attempts"; Westen, "The Ontological Problem of 'Risk"”.

86 Westen, "The Ontological Problem of 'Risk"', pp. 323-324.

87 Westen, "The Ontological Problem of 'Risk", p. 327. See, similarly, Peter Westen, "Resulting Harms and Objective Risks as Constraints on Punishment", Law and Philosophy, 29(4) (2010): pp. 401-418, 413.
} 


\section{Objections and Clarifications}

It is useful to begin by noting that the case for complicating the analysis of recklessness in the manner described in the previous section is (even) stronger than that in relation to "factually impossible" attempts that are obviously doomed to failure. Attempts are "attacks". ${ }^{88}$ Through intending to bring about harm, and taking (from his perspective) more than merely preparatory steps towards doing so, the defendant "relates himself as an agent as closely as he can to that harm". ${ }^{9}$ That connection between agency and the world is looser when reckless endangerment of interests is involved; the defendant is not intending to cause harm. With that loosening comes a less secure basis for condemnation and deserved punishment.

Similarly, there may_-given the defendant's aim in bringing about the ultimate crime-be a worry that the attempt may be repeated in circumstances where the crime can be completed. ${ }^{90}$ Even if this worry is grounded empirically, ${ }^{91}$ it is an unsatisfactory answer in the context of attempts, being premised on anticipated future criminality (with all of the epistemic difficulties that involves), and not present wrongdoing and culpability. ${ }^{92}$ It is even less convincing in the context of reckless endangerment. Even in real (and obviously threatening) cases like Parker, it is unduly paranoid to worry that this is the first arson-based home improvement scheme of many, and hold that this is sufficient reason to punish the defendant now. Even where the defendant has a cavalier attitude towards risks (perhaps Kasper frequently demonstrates an insufficient regard for his children's lives in his practical reasoning), punishing him where he unreasonably believes that he is exposing them to the risks of death/serious injury is redolent of pre-punishment for an anticipated undesirable choice or an extant character trait. The reasonableness requirement suggested here ensures that the state can only intervene when the defendant does something that plausibly engages the world of risk in a threatening manner, respecting familiar concerns of privacy and individual autonomy. ${ }^{93}$ It is through such conduct that

\footnotetext{
${ }^{88}$ Duff, Criminal Attempts, pp. 363-366. On the general stability of the attacks/endangerment distinction, see Kimberly Kessler Ferzan, "The Structure of Criminal Law", Criminal Justice Ethics, 28(2) (2009): pp. 223-237, 229-231; Stark, Culpable Carelessness, pp. 223-225.

${ }^{89}$ Duff, Criminal Attempts, p. 366. See, also, R.A. Duff, "Criminalizing Endangerment", in R.A. Duff and Stuart Green (eds.), Defining Crimes: Essays on the Special Part of the Criminal Law (Oxford: Oxford University Press, 2005), p. 58.

${ }^{90}$ Gerald Gordon, The Criminal Law of Scotland: Vol. 1, 3rd edn. by M.G.A. Christie (Edinburgh: Scottish Universities Law Institute, 2000), p. 219; Sarah Christie, "The Relevance of Harm as the Criterion for the Punishment of Impossible Attempts", Journal of Criminal Law, 73(2) (2009): pp. 153-164.

${ }^{91}$ For doubts, see Seana Shiffrin, "The Moral Neglect of Negligence", in David Sobel, Peter Vallentyne and Stephen Wall (eds.), Oxford Studies in Philosophy: Vol. 3 (Oxford: Oxford University Press, 2017), p. 217.

${ }_{92}$ See, further, Stefanie Bock and Findlay Stark, "Preparatory Offences", in Kai Ambos, R.A. Duff, Julian V. Roberts, and Thomas Weigend (eds.), Core Concepts in Criminal Law and Justice: Vol. 1 (Cambridge: Cambridge University Press, forthcoming).

93 Duff, Criminal Attempts, p. 350; Kenneth Simons, "Does Punishment for 'Culpable Indifference' Simply Punish for 'Bad Character'?’, Buffalo Criminal Law Review, 6(1) (2002): pp. 219-316, 231-233.
} 
citizens make their concern for others (a facet of their characters) susceptible to public examination in the way involved in criminal prosecution. ${ }^{94}$

Over-zealous public examination of citizens' activities is a large cost of Alexander and Ferzan's belief-centred view-a cost they acknowledge, ${ }^{95}$ but is more important than they accept. As Alec Walen puts the point: "The degree of intrusiveness necessary to police wrongful risk imposition would be unbearable, and the epistemic difficulties in sorting out who really believed what about the risks they were imposing on others would be insurmountable." 96 Viewing any action (carried out with the relevant set of beliefs) as a potential offence of reckless endangerment means that the usual evidence for inferring such a belief (the dangers that are reasonably thought to flow from action) will be absent, or at least less convincing. Absent reliable confession evidence, such cases may be difficult or impossible for finders of fact to assess consistently and well.

Alexander and Ferzan will point out (rightly) that these points are irrelevant to moral culpability, and (plausibly) that these epistemic difficulties will not always be insurmountable. But it is not clear that Walen's concerns are so easily parried in the context of a real-world criminal justice system. Although this might seem to be a mixing and matching of conceptual and institutional arguments, ${ }^{97}$ that is only problematic if one has accepted that moral culpability is the be-all-and-end-all of legal culpability. ${ }^{98}$ The risk of over-intrusiveness at issue in this paper is a good reason against accepting that view. A reasonable belief-based view provides a necessary safety buffer. Many aspects of the criminal justice system (for example, the burden and the high standard of proof placed on the prosecution) $)^{99}$ already reach a similar compromise, and with good reason, given the horrendous consequences of punishing the innocent.

These points are in tension with the fact that the criminal law is (rightly) very concerned with guiding conduct, and that investigating the reasonableness of the defendant's beliefs about risk in cases of recklessness removes a degree of ex ante clarity. Alexander and Ferzan may claim that their account pays supreme respect to the guidance function: actors are judged on their beliefs (whether reasonable or not) and choices, and it is these, not what is factually the case or reasonable, that guide conduct. ${ }^{100}$ From a practical reasoning perspective, the cases discussed in this article

\footnotetext{
94 For a similar suggestion, see Tadros, The Ends of Harm, p. 96.

95 E.g., Alexander and Ferzan with Morse, Crime and Culpability, p. 232.

96 Alec Walen, "Crime, Culpability and Moral Luck", Law and Philosophy, 29(4) (2010): pp. 373-384, 381. See, similarly, Westen, "Resulting Harms", pp. 402-403.

97 Cf. Kimberly Kessler Ferzan, "Review of Findlay Stark, Culpable Carelessness", Modern Law Review, 81(6) (2018): pp. 1092-1096, 1095.

98 Alex Sarch explores a (not dis)similar sort of distinction in "Who Cares What You Think? Criminal Culpability and the Irrelevance of Unmanifested Mental States", Law and Philosophy, 36(6) (2017): pp. 707-750.

99 At times, it appears that the high standard of proof is the only protection Alexander and Ferzan think necessary: Crime and Culpability, pp. 318-320.

100 Alexander and Ferzan with Morse, Crime and Culpability, p. 195. Cf. Jonathan Way and Daniel Whiting, "Perspectivism and the Argument from Guidance", Ethical Theory and Moral Practice, 20(2) (2017): pp. 361-374.
} 
are indistinguishable. ${ }^{101}$ The belief-centred view of recklessness, in treating all of these cases alike, recognises this point.

This is, however, a perversion of the law's guidance function, not an embrace of it. Granted, the criminal law cannot plausibly direct actors on the basis of the facts, because those facts will, ex ante, often be unknowable (particularly when a future result is at issue). The most obvious contrary position is not, however, to hold that the criminal law exists to guide the unreasonable and the grossly misguided. ${ }^{102}$ The better position, it is suggested, is that the criminal law's instructions and prohibitions are directed towards actors with reasonable beliefs (stemming from the evidence available to them) about the dangers to which they are exposing others. ${ }^{103}$

Alexander and Ferzan may respond that such rules about reasonableness are nevertheless wrongheaded, and the approach proposed here will be arbitrary in practice, in comparison with the simple(r) outcomes suggested by their belief-centred view of recklessness. ${ }^{104}$ Finders of fact will disagree about whether it was reasonable to believe that a risk of the relevant "concrete" danger existed. There are the familiar worries about what knowledge is ascribed to the ordinary, knowledgeable observer/ taken into account when assessing reasonableness. ${ }^{105}$ And it must be remembered that these already vague judgements will be made by laypersons without special training.

Reasonableness is often a vague standard, as are its equivalents. ${ }^{106}$ But such vagueness is more obviously problematic when it is used in an inculpatory than an exculpatory fashion. Inculpation using a vague standard is, indeed, something that the criminal law should avoid where it can. ${ }^{107}$ That is one reason not to use negligence liberally in the criminal law. ${ }^{108}$ But the proposed reasonable belief standard suggested in this article would not convict anybody who would be acquitted under Alexander and Ferzan's scheme. It will, instead, lead to the intuitively acceptable acquittal of a (small) number of defendants Alexander and Ferzan's approach would

\footnotetext{
101 Morse, "Criminal Responsibility", p. 391.

102 Unreasonable and (perhaps) grossly misguided persons may, of course, still be capable of being guided by reasonableness, even if the position they can appreciate as being the "reasonable" one is, for them, unacceptably paranoid/relaxed.

103 This point is usually masked by a more common focus on the requirement that citizens form reasonable beliefs to avoid liability, rather than as a condition of such liability existing. Negligence, for example, requires that defendants form reasonable beliefs about the risks associated with their conduct; reasonableness of belief perhaps ought to be required to avoid liability for mistakes in defences (though I cannot defend that claim here: see, further, Morse, "Criminal Responsibility").

104 See their critique of the reasonable person test in negligence in Alexander and Ferzan with Morse, Crime and Culpability, pp. 81-85.

105 Larry Alexander and Kimberly Kessler Ferzan, "Response to Critics", Law and Philosophy, 29(4) (2010): pp. 483-504, 490-491; Westen, "The Ontological Problem of 'Risk",, p. 321. For similar worries about a requirement of "minimal rationality" in the context of factually impossible attempts, see Richard Lippke, "Harm Matters: Punishing Failed Attempts", Ohio State Journal of Criminal Law, 14(2) (2017): pp. 629-646, 645.

106 Douglas Husak, "Why Punish Attempts at All? Yaffe on the 'Transfer Principle", Criminal Law and Philosophy, 6(3) (2012): pp. 399-410, 408-409.

107 See Alexander and Ferzan with Morse, Crime and Culpability, p. 63.

108 See Stark, Culpable Carelessness, pp. 260-266.
} 
convict. True, the line between conviction and acquittal will never be crystal clear. Some defendants will be treated harshly, others leniently. Convicting everyone, and depriving those with unreasonable beliefs of possible acquittals, is nevertheless an odd response to this fact.

Finally, it is worth pointing out that a degree of vagueness is not alien to Alexander and Ferzan's view. They allow the defendant who believes her risk-taking is justified (shows sufficient regard for the interests of others) to be held liable where her choice to $\Phi$ in fact manifests insufficient concern for the interests of others. ${ }^{109}$ This view is plausible. Taking the defendant's beliefs about what is sufficient concern for others to be determinative would take some of the worst risk-takers beyond the criminal law's reach, i.e., those who are so unconcerned with the interests of others that they think extreme risk-taking is justified, when a more "objective" view would reach a different conclusion. ${ }^{110}$ Any assessment of justification/sufficient concern other than the defendant's is going to be just as susceptible to variation and opacity as the reasonableness constraint on recklessness defended here. ${ }^{111}$ Ultimately, the question is whether there is simply "too much" arbitrariness if one goes beyond Alexander and Ferzan's limited concession to a more "objective" perspective. It is not clear whether there is any answer to this question that is not, well, arbitrary.

Now that obvious objections to a requirement of reasonableness in recklessness have been dealt with, consideration will be given to how it could be implemented.

\section{Recognising Reasonableness Within Recklessness}

To recapitulate, if the defendant's belief that she may "concretely" endanger others was reasonable, then she should be convicted of an offence premised on reckless endangerment of a particular interest, even if nobody was, in fact, "concretely" endangered.

If the defendant's belief that "concrete" dangers may be associated with $\Phi$ ing was unreasonable, however, only a slight degree of moral culpability-based justice is lost, and much else is preserved, through acquitting such defendants of offences premised on reckless endangerment.

Courts have, at times, appeared to grasp these points. In Sangha, ${ }^{112}$ for example, the (English and Welsh) Court of Appeal concluded that there was no need to prove "concrete" endangerment of life in aggravated criminal damage, so long as ${ }^{113}$ :

\footnotetext{
109 Alexander and Ferzan with Morse, Crime and Culpability, p. 59.

110 Stark, Culpable Carelessness, p. 24.

111 See Simons, "Retributivism Refined", pp. 579-583. Alexander and Ferzan now seem more concerned about cases of "moral ignorance", where similar errors are made. See Larry Alexander and Kimberly Kessler Ferzan, Reflections on Crime and Culpability: Problems and Puzzles (Cambridge: Cambridge University Press, 2018), Ch. 6.

112 [1988] 1W.L.R. 519 (E\&W).

113 At 525.
} 
[The] ordinary prudent bystander would have perceived an obvious risk that property would be damaged and that life would thereby be endangered. ... The ordinary prudent bystander is not deemed to be invested with expert knowledge relating to the construction of the property, nor to have the benefit of hindsight. The time at which his perception is material is the time when the fire is started.

The Court of Appeal's decision was handed down at a time when Caldwell's ${ }^{114}$ more "objective" understanding of recklessness reigned. During the Caldwell era, the defendant's "subjective" belief that the relevant risk existed was not a necessary component of recklessness. In consequence, the Court of Appeal in Sangha grasped only part of recklessness - that the relevant risk (of "concrete" endangerment of life) must be one that it would be reasonable to believe existed at the time the defendant acted. The other elements of recklessness (under-played during the Caldwell era) are that the defendant must have that reasonable belief himself, and choose to proceed without adequate justification. The modern English definition of recklessness in criminal damage, provided by the House of Lords in $G$ and Another, grasps these other points: "A person acts recklessly ... with respect to (i) a circumstance when he is aware of a risk that it exists or will exist; (ii) a result when he is aware of a risk that it will occur; and it is, in the circumstances known to him, unreasonable to take the risk." 115 One can only be "aware" of something if one believes it to be the case.

"Awareness", as noted above, goes beyond this: it is a "factive" mental state, and incorporates a truth claim. If "true" risk is understood in terms of a reasonable belief that a particular risk exists, the $G$ and Another definition of recklessness in terms of "awareness" of risk could be interpreted in line with this article's argument. There is a danger, however, that "awareness" of risk may be misunderstood to require proof of actual, "concrete" endangerment. The arguments about "concrete" endangerment in this paper provide additional reasons, ${ }^{116}$ then, to reject definitions of recklessness (and negligence) in "factive" terms such as awareness, knowledge, recognition, or realisation of risk, lest these be mis(understood) to require "concrete" endangerment. Although such "factive" terminology is common in the Anglo-American world, it may be confusing in terms of everyday speech. ${ }^{117}$ It would be preferable to define recklessness in terms of reasonable beliefs about risk.

The definition of recklessness that I provided in my earlier book ${ }^{118}$ could be amended easily to accommodate the argument made above (the change is in square brackets) ${ }^{119}$ :

\footnotetext{
114 [1982] A.C. 341 (E\&W).

115 [2004] 1 A.C. 1034, [41] (E\&W) (quoting from Law Commission, A Draft Criminal Code for England and Wales: Vol. 1 (Law Com. No. 177, 1989) cl. 18).

116 For others, see Stark, Culpable Carelessness, Ch. 5.

117 On the importance of such "everyday" understandings of words in the criminal law: see Stark, Culpable Carelessness, Ch. 3.

118 Stark, Culpable Carelessness, p. 277.

119 There is no need to amend the definition of negligence, because-when understood in terms of the absence of a belief about risk-it is already implicitly asking a question about reasonable beliefs.
} 
Recklessness: A person is reckless with regard to a risk that a particular piece of conduct will be engaged in, consequence will occur or circumstance will exist (the relevant risk) where he: (i) [reasonably] believed that the relevant risk was connected with his behaviour and (ii) failed to alter his behaviour, in circumstances where this demonstrated insufficient concern for the interests of others. The belief that the relevant risk existed need not be at the forefront of the defendant's mind at the time of acting.

In the run of cases, this understanding of recklessness will achieve justice. As the next section explains, there is, however, one exceptional case where the reasonable belief-based view of recklessness defended in this article should bend.

\section{Over-Estimation Cases}

Consider a case where Carrie believes that, by driving near a school at $50 \mathrm{mph}$ in a $30 \mathrm{mph}$ zone at break time (recess), she is imposing a substantial risk of death on pedestrians. ${ }^{120}$ This is a risk that, it is assumed, it would be unjustified for her to take. The children are, in fact, in class. Although it will depend on the precise circumstances, this may be a situation where: (i) it would have been reasonable for the defendant to believe that the probability of harm $x$ was lower than what she, in fact, believed, but (ii) the risk of harm $x$ that it would have been reasonable to believe existed would still have been unjustified to take, in all the circumstances. In such cases, the defendant is sufficiently culpable to be held liable for recklessly risking harm $x$, despite her unreasonable over-estimation. Carrie's may well be such a case, if the children are obviously absent, but it would nevertheless have been reasonable for Carrie to believe that driving $20 \mathrm{mph}$ above the posted speed limit carried with it a substantial risk of killing someone (a risk that she had no justification for taking).

The same is true of "result crimes" 121 where, ex ante, the defendant unreasonably over-estimated the risk of the relevant harm. ${ }^{122}$ For example, Sally believes that the risk of killing someone by driving at the posted speed limit is incredibly high, yet chooses to do so. Frank emerges suddenly from a hidden alleyway next to the road, and is run over by Sally and killed. Sally should only be counted as having been reckless regarding killing another person if the danger of death that it would have been reasonable to have believed existed, ex ante, was, in the circumstances, unjustified for her to take. Here, that seems unlikely (assuming normal weather conditions, etc.), and this should preclude liability for a homicide offence that requires recklessness with regard to the caused death.

\footnotetext{
120 This is an amended version of an example provided in Robinson, "Prohibited Risk Creation", p. 387. Another familiar example is a defendant who believes, because her speedometer is broken, that she is travelling much faster than she, in fact, is, and is thus taking far higher risks with others' interests. See Alexander and Ferzan, "Response to Critics", p. 493; Robinson, "Prohibited Risk Creation", p. 388.

121 See Gordon, Criminal Law, p. 59.

122 This point is noted in Robinson, "Prohibited Risk Creation", p. 376.
} 
To cater for such cases, the following rule could be appended to the definition of recklessness given above:

Recklessness (over-estimation cases): Where a person unreasonably over-estimates the extent of the relevant risk, he is nevertheless reckless regarding that relevant risk if a failure to alter his behaviour, in the light of the level of the relevant risk that it would have been reasonable to believe existed at the time he acted, would have demonstrated insufficient concern for the interests of others.

This solution covers cases of unreasonable over-estimation. It is worth stating explicitly that, in both endangerment and result crime scenarios, if the defendant under-estimates the relevant risk unreasonably, then she cannot be reckless with regard to the relevant risk. She might be negligent with regard to the relevant risk, but that is a different question altogether. ${ }^{123}$

\section{Conclusion}

The intuitive worries raised by Sarch's and Robinson's examples raise deeper questions about the extent to which moral culpability markers such as choices demonstrating insufficient concern for others should rule decisions about legal culpability, the scope of offences of endangerment, and when a defendant should be punished in the real-world context of a criminal justice system, with its appropriate circumspection about imposing punishment upon citizens. ${ }^{124}$ The answer presented here is that, in the run of cases, a belief-centred view of recklessness that does not interrogate the reasonableness of those beliefs will indicate acceptably the boundaries of legitimate punishment, and that it would over-privilege various forms of luck to let liability to punishment depend on whether a person's interests were, in fact, "concretely" endangered by the defendant's conduct. Taken to extremes, however, a belief-centred view of recklessness conduces to harshness, invasiveness, and error. The preferable middle path (barring the cases of over-estimation dealt with in Sect. 7) is one premised on whether the defendant's belief that his conduct could "concretely" endanger others is reasonable.

Acknowledgements I am grateful to Christopher Cowley and Beatrice Krebs for inviting me to participate in the "Recklessness and Negligence Workshop", University of Reading, 21-23 June 2018 (albeit remotely, due to ill health). I am further grateful to Christopher Cowley, Alexander Greenberg, Matt Matravers, Alex Sarch, and an extremely helpful anonymous reviewer, for criticisms of earlier drafts.

Open Access This article is distributed under the terms of the Creative Commons Attribution 4.0 International License (http://creativecommons.org/licenses/by/4.0/), which permits unrestricted use, distribution, and reproduction in any medium, provided you give appropriate credit to the original author(s) and the source, provide a link to the Creative Commons license, and indicate if changes were made.

Publisher's Note Springer Nature remains neutral with regard to jurisdictional claims in published maps and institutional affiliations.

\footnotetext{
123 See Stark, Culpable Carelessness, Ch. 8.

124 A distinct way of putting this argument is in terms of the duty of the state not to push retributive desert unrelentingly. I am grateful to Alex Sarch for suggesting this to me.
} 